\title{
THE DEVELOPMENT OF THE WORLD FLEET OF ELECTRIC VEHICLES IN YEARS 2010-2017 WITH EMPHASIS ON FUEL-CELL VEHICLES
}

\author{
Wojciech Gis, Maciej Menes \\ Motor Transport Institute \\ Jagiellonska Street 80, 03-301 Warsaw, Poland \\ tel.: +48 22 4385400, fax: +48224385401 \\ e-mail:wojciech.gis@its.waw.pl,maciej.menes@its.waw.pl
}

\begin{abstract}
The article discusses the development of the world EV fleet in years 2010-2017. Estimates of fleet of plug-in hybrid electric vehicles (PHEV) and BEV in the world are presented. The total number of PHEVs registered in the world in 2016 was roughly 800 thousand (650 thousand in EU). Despite the fact that the sale of electric vehicles has increased considerably in recent years, in particular over 1.1 million in 2017, and also hybrid electric vehicles (PHEV) to approx. 760 thousand in 2017. The article also discusses the development of the electric vehicles market and annual new registrations of vehicles in a breakdown into respective countries. China is the definite leader in this area. In 2017 there were almost twice more BEVs registered in China than in the US and EU together. While the increase in the sale of BEVS in years 2016-2017 in the EU and the US accounted for approx. 50\%, it came to over 90\% in China. Among eight top worldwide BEV producers, there are four Chinese manufacturers. In the analysed 2017, there were slightly more than 7 thousand of hydrogen-fuelled passenger cars (FCEV) in use, with over 3,500 in the US, 2,300 in Japan and approx. 1,200 in Europe, and several hundred hydrogen-fuelled buses and several dozen hydrogen-fuelled trucks. The article also addresses the development of hydrogen refuelling stations (HRS) in recent years in different countries in the world, bearing in mind that the quantitative development of the hydrogen-fuelled car fleet is strongly associated with the number of hydrogen refuelling stations.
\end{abstract}

Keywords: passenger cars, electric vehicle, fuel cells, hydrogen, environment

\section{Introduction}

Works on the use of hydrogen as an energy carrier have a long-standing tradition; however, they entered a dynamic pace combined with efforts to popularise the solutions only in 2000 s and more precisely - at the turn of the first and second decade of the $21^{\text {st }}$ century. In years 2005-2014 members of the Hydrogen Council, established in 2017, alone spent over a billion euro annually on studies on the use of hydrogen for energy and commercialisation of the results. Those expenditures in years 2015-2017 amounted to approx. EUR 1.4 billion annually and in the 5-year period from 2018 to 2022, they are expected to come near to EUR 2 billion yearly [11].

Works on the hydrogenization of means of transport were initiated already at the turn of $1980 \mathrm{~s}$ and 1990s. In the initial phase, efforts focused on the hydrogenization of means of road transport, in particular the hydrogenization of the drive system in passenger cars.

\section{Vehicles equipped with hydrogen fuel cells}

Cars with hydrogen drive systems in the form of concept vehicles began to emerge in 1990s. Examples include three models of Daimler-Chrysler NECAR1/2/3 of 1994-1997, three models of Toyota FCHV1/2/3 of 1992-2001, four models of Honda FCXV1/2/3/4 of 1999-2001 and three models of General Motors Hydro GEN 1/2/3 FCV of 2001-2004 and 5 models of Chinese manufacturers, i.e. Cherry Automobile Co. Ltd, Saic Motor Co. Ltd, Chang, an Automobile Co. Ltd and Foton Motor Co. Ltd. 
With the start of 2000s, the first test models of fuel-cell vehicles were released for use: Honda FCX FCV (2002-2007), Ford Focus FCV (2003-2006), Nissan X Trail FCV (2003-2013), Mercedes Benz F-Cell (2005-2007), Chevrolet Equinox FCV (2007-2009).

In subsequent years leading motor companies presented their concept models of hydrogenfuelled vehicles - among them Volkswagen (Golf Sport Wagen HyMotion and Crafter Hymotion 4.2 tonne van), Audi (A7 Sportback h-tron quattro), Lexus (LF-FC), Kia, BMW (5GT), Ford, Mazda (RX-8), Chevrolet (Colorado ZH2) and Nissan (Xterra FCV).

Concurrently with testing passenger cars with hydrogen drive systems, usually within the framework of various demonstration projects, the first FCEV buses were presented, e.g. EU project JHFC (2000-2010) and US FC bus project (2006 till present).

The first limited-run production of hydrogen-fuelled vehicles (several hundred cars annually) of ix35 Fuel Cell was launched by Korea-based Hyundai Motor Company in 2013. In 2014 it was joined by Toyota with its hydrogen-fuelled model Mirai, also produced on a limited scale (700 cars in 2015), which reached the level of 3,000 vehicles per year only in 2017. In 2014 the next version of its hydrogen vehicle SAIC/ROVER 950 was presented by the China-based Saic Co. Ltd. [1]. The same company presented in 2017 a multi-seat hydrogen hybrid plug-in vehicle.

In 2016, Honda joined manufacturers of hydrogen-fuelled vehicles with its FVEC Clarity model and in 2018 by Mercedes-Benz with hydrogen-fuelled plug-in hybrid GLC-F-Cell [17]. The manufacturers of hydrogen-fuelled vehicles also include the French Symbio FCell, which manufactures a plug-in hybrid Symbio FC-Kangoo-ZE-HE. In this light van, hydrogen fuel cells play the role of a range-extender.

The start of FCEV production in 2020 has been announced among others by Mazda, BMW, Audi and Kia. Because of the limited production of hydrogen-fuelled vehicles, so far the world fleet of those vehicles is small. In 2017 there were just 7,200 hydrogen-fuelled vehicles used in the world (3,500 in the US, 2,300 in Japan and 300 in Germany, 260 in France and approx. 100 in each South Korea, Norway and the UK) [2].

In 2018 the world fleet of hydrogen-fuelled vehicles increased to roughly 13,000 cars $(5,900$ in the US, with the majority in California, and 2,900 in Japan, 1,500 in China, approx. 500 in South Korea, c.a. 500 in Norway and 300 in France).

Since 2015, the taxi network Hype in Paris has been using 100 Toyota Mirai vehicles, which presently can use 4 public hydrogen-refuelling stations. Ultimately, by 2020 the number of Toyota Mirai taxis used by this one Parisian taxi company only is planned to expand to 600 cars.

According to the current versions - considerably limited compared to assumptions made in the period from 2005 to 2015 - of the most advanced plans regarding the development of hydrogenization in motor transport, the global fleet of hydrogen-powered vehicles is expected to increase up to several thousands in 2020 (Japan - 40,000, China 5,000, South Korea 10,000, California 18,500) [2] and in 2025 there will be roughly 300-400 thousand vehicles (Japan 200,000, South Korea 30,000, China 50,000, California 75-150,000).

According to forecasts made in 2014, the European fleet of hydrogen-fuelled vehicles was estimated to reach 350,000 vehicles, in Japan - 100,000, in Korea - 50,000 and in the US - 20,000 in 2020 [18]. In Japan alone, the sale of FCEVs in 2020 is expected to exceed 10,000 vehicles and Toyota, which presently sells FCEVs in 11 countries, is planning to increase its production up to 30,000 cars annually in 2025.

In addition to hydrogen, passenger cars Toyota launched hydrogen-fuelled bus Sora and initiated works in the US on hydrogen Class 8 trucks (Project Portal 2.0). Within the scope of the project constructed were a medium-tonnage hydrogen-fuelled vehicle "Beta" with a driving range of $480 \mathrm{~km}$ and hydrogen-fuelled high-tonnage (36 t dmc) "Alfa" with $320 \mathrm{~km}$ driving range, with its first models in the form of garbage trucks put into use in the Los Angeles area in 2017 [3]. Toyota expects that before the Olympic Games in Tokyo in 2020 more than 100 hydrogen-fuelled buses will be used in Japanese towns. 
Korea-based Hyundai presented just as ambitious plans. The company introduced into the market its new flag vehicle with hydrogen drive NEXO in 2018. Apart from next generation fuel cells with capacity of $95 \mathrm{~kW}$ guaranteeing a driving range of $600 \mathrm{~km}$, the car is equipped with a number of advanced systems supporting the driver and allowing for full self-drive (the vehicle's model presented during Winter Olympic Games in Pyeongchang in 2018 completed a self-driven journey of 120 miles from Seoul to Pyeongchang [13]) More than 1000 vehicles were sold in the first week of the sales, despite the high price of US 65,000 (covered in half by governmental and regional subsidies). The company is planning to exceed the production volume of 50,000 FCEVs in 2030 [4].

Based on the doubled fuel cell systems applied in NEXO passenger car, Hyundai constructed a hydrogen-fuelled truck with load of 18 tonnes (34 $\mathrm{t} \mathrm{dmc}$ with a tractor unit) with a driving range of $400 \mathrm{~km}$. A thousand of those vehicles will be delivered to Switzerland in years 2019-2023. Hyundai also intends to launch the production of medium-tonnage (4-5 tonne) hydrogen-fuelled vehicles.

Apart from the aforementioned major motor companies, many specialised manufacturers such as Belgian Van Hool, Polish Solaris, Wrightbus from Northern Ireland, Thor Industries Inc. based in the US, Iveco Bus, Hino Motors from Japan or Chinese companies Zhongtong Bus Holding Co Ltd, Foshan Auto Group, Beigi Foton Motor Co. Ltd, Zhengzhou Youtong group Co. Ltd. are committed to the construction of fuel-cell electric buses.

Among truck manufacturers the most popular companies are based in the US: Nikola Motor Company whose prototype truck Nikola Tre equipped with $120 \mathrm{~kW}$ fuel cells is to be launched for sales in 2022-2023 (a purchase option in the excess of 1.3 billion dollars was made for those vehicles by December 2018) and Navistar owned by TransPower, which is planning to launch the production of hydrogen-fuelled Class 8 vehicles this year.

In 2019/2020 introduced into the market will be hydrogen-fuelled trucks by Scania cooperating with Hydrogenics and PowerCell [5]. Prototypes of hydrogen-fuelled trucks have been developed also in China, among others in the production plants of Dongfeng cooperating with Ballard, in US Fuel Cell plants owned by US Hybrid and Chinese Dewei.

The dynamic pace of the development and the growing share of the Chinese motor industry in the hydrogenization of motor transport are illustrated by data of the catalogue prepared by the Chinese Ministry of Industry and Information Technology (MIIT), which promotes hydrogenfuelled vehicles (eligible for governmental subsidy are only vehicles included in the catalogue), presenting 75 models of different types of hydrogen-fuelled vehicles, including more than 20 hydrogen-powered buses [16].

In 2018, Hyundai showed its flag hydrogen-fuelled vehicles NEXO. Besides the next generation fuel cells, the vehicle is equipped with a number of advanced systems supporting the driver and allowing for full self-drive.

In 2018, also Daimler presented another hydrogen-fuelled vehicle. GLC F-Cell constructed on the platform of a conventional car is the first plug-in hybrid with a hydrogen technology drive. The most recent forecasts confirm that the production of hydrogen vehicles will increase gradually in the forthcoming years - from approx. 4000 cars in 2016 to 8,500 in 2019, 16,600 in 2022, 41,200 in 2025 and approx. 70,000 in 2027 [14]. In 2019, Symbio and Mercedes Benz joined motor company's manufacturing such vehicles, i.e. Toyota, Hyundai and Honda. They will be followed by Lexus and Kia (2019) and BMW, Ford, Mazda, Nissan (2022) and Audi, Chevrolet, GMC and Volkswagen (approx. 2025).

\section{Hydrogen refuelling stations}

In 2018, there were 369 hydrogen-refuelling stations in the world (including 273 public), of which 152 were in Europe, 136 in Asia and 78 in North America [10]. 
It is worth noticing that the number of hydrogen refuelling stations increases dynamically from 26 in 2012 to 180 in 2015, 263 in 2016 and 330 in 2017 [9]. According to recent forecasts the number of HRS is expected to increase up to 1,000 in 2020 and approx. 3,500 in 2025 [8]. The greatest number of HRS is in the following countries: Japan (more than 100), the US (65), Germany (60), France and China (21 each), the UK (18) and South Korea (17) [15]. Worldwide HRS suppliers include: AGA Industrial Gases (Sweden), Air Liquid (France), Air Products (USA), First Element Fuel (USA), H2Energy AG (Switzerland), Hyundai Motor Company (South Korea), Idemitsu Kosan (Japan), ITM Power (UK), Iwatani (Japan), Linde AG (Germany), McPhy Energy (France), Nel Hydrogen Fuelling (Norway), Proton Onsite (US), Uno-X Hydrogen (Norway) [6].

\section{Fully electric vehicles and hybrid plug-in vehicles}

BEVs and plug-in PHEVs are the main pillars of electrification in the global car fleet besides fuel-cell vehicles using hydrogen.

The world PHEV fleet increased from roughly 10,000 cars in 2011, 70,000 thousand in 2012, 167,000 in $2013,305,000$ in $2014,576,000$ in $2015,897,000$ in 2016,1213 thousand in 2017 up to 1.9 million in 2018. This does not change the fact that PHEVs still account for merely $0.5 \%$ of the world car fleet.

In Europe - where the sale of PHEV in 2018 exceeded 170,000 cars - they were the most popular in Germany (approx. 31,000 vehicles) and in the UK (slightly more than 44,000). On a global scale the largest number of PHEVs was sold in 2018 in China (271,000 vehicles) and in the US (roughly 120,000 vehicles).

In 2018 the largest number of PHEVs was in China $(630,000)$, the US (c.a. 475,000), Japan $(127,000)$ and the Netherlands $(106,000)$. Substantial PHEV fleets were in the UK $(135,000)$, Germany (approx. 92,000) and Norway (c.a. 90,000).

In 2010 there were just 16,000 battery electric vehicles registered in the world. Since then the sale of BEVs started to grow dynamically up to 40,000 in $2011,62,000$ in $2012,166,000$ in 2013 , 193,000 in 2014, 440,000 in 2015, 633,000 in 2016, 973,000 in 2017 and 1.5 million in 2018.

Until 2015, those vehicles consisted almost solely of passenger cars, but from 2015, electric high-tonnage (buses and trucks) started to become more popular, produced mostly in China.

In 2015 the Chinese production of electric vehicles comprised 212,000 passenger cars and 124,000 high-tonnage vehicles, in 2016 respectively 351,000 and 171,000, in $2017-602,000$ and 196,000 and in 2018 respectively approx. 1000 thousand and 275,000.

The overall Chinese production of plug-in BEVs and PHEVs accounted for $0.46 \%$ (2015) to $58.5 \%$ (2017 and 2018) of the world production of such vehicles.

The world fleet of BEVs increased in 2011 from approx. 55,000 vehicles, in 2012 - to 115,000, in 2013 - to 229,000 , in 2014 - to 420,000 , in 2015 - up to 850,000 , in 2016 - to approx. 1.5 million, in 2017 - to 2.4 million and in 2018 - to 3.9 million vehicles. The largest BEV fleet in 2018 was in China (2.37 million), the US $(642,000)$, Norway $(190,000)$, Japan $(141,000)$, France $(122,000)$ and Germany $(102,000)$. Despite dynamic increase in years 2010-2018 of the world $\mathrm{BEV}$ fleet, they continue to account for just $0.3 \%$ of the total number of vehicles registered in the world.

The overall cumulated sales, corresponding more or less to the number of registrations, of plug-in electric vehicles, comprising BEVs and PHEV can be estimated at approx. 5.8 million in years 2010-2018, with a fleet of slightly over 60,000 in $2011,184,000$ in 2012 and c.a. 0.4 million in 2013, roughly 700,000 in 2014, approx. 1.4 million in 2015, over 2.3 million in 2016, over 3.7 million in 2017 and over 5.8 million in 2018.

Among 5.8 million plug-in electric vehicles used in the world in 2018, more than 2.9 million were used in China, roughly 1.1 million in the US, over 1.2 million in Europe, mostly in Norway (approx. 272,000), with c.a. 920,000 used in EU member states, and the most in the UK $(199,000)$ 
and in Germany $(194,000)$. However, the overall number of plug-in vehicles (BEV and PHEV) in 2018 still accounted for little over $0.45 \%$ of the global fleet of passenger cars.

Despite a considerably more dynamic sale of plug-in electric vehicles, especially in the past few years, from 6,500 in 2010 to approx. 2.2 million in 2018, including an increased sale of PHEVs from several hundred vehicles in 2010 to approx. 620,000 in 2018 and BEVs from 6,000 in 2010 to up to 1.5 million in 2018 , those volumes are still much lower than the volumes predicted at the beginning of 2000s. According to the last IEA forecast of 2018 in 2020, the global fleet of electric vehicles is expected to consist of 13 million and in $2030-130$ million vehicles [7].

\section{Summary}

The adjustments in the forecast development of electromobility do not change the fact that electric vehicles are already becoming a true element of the automotive market both in the scale of respective countries and globally.

This tendency will most likely be strengthened in the forthcoming years by the development of the fuel-cell vehicles fleet (though delayed by 7-10 years compared to the initial assumptions). Most experts assume that by 2050 hydrogen-fuelled vehicles will become an important element of the global fleet of motor cars. In complementarity with BEV, they will account for most of the vehicles produced and their share in the fleet will increase up to $25 \%$ among passenger cars (400 million), 30\% among trucks ( 5 million) and up to 25\% among buses (15 million) [12].

\section{References}

[1] Chine: le programme, Hydrogene de les piles a combustible, Association francaise pour l'hydrogene et les plies Combustible memento pour l'hydrogen, Fiche 86, p. 8, Paris 2018.

[2] Closer look at the deployment of the fuel-cell EVs as December 2017, https://www.leaffuel cell.com/.../AFC\%20TCP_survey\%20status\%20.

[3] Fuel Cell Bulletin, May 2018.

[4] Fuel Cell Bulletin, p. 3, October 2018.

[5] Fuel Cell Bulletin, p. 2, January 2019.

[6] Fuel Cell Technologies Market Report, US Department of Energy, Office of Energy Efficiency and Renewable Energy, Washington, pp. 21-22, October 2017.

[7] Global Ev outlook 2018, towards cross-model electrification, OECD/IEA, pp. 77, 2018.

[8] H2 Mobility, US DOE, Hydrogen Europe, Air Liquid after: How hydrogen empowers the Energy transition, Hydrogen Council, p. 9, 2017.

[9] Harrison, P. et al., Fuelling Europe's Future, CFLPA, Euroelectric, European Climate Foundation, Nissan, SSE, Transport \& Environment, Cambridge Econometrics, 2013.

[10] Highest increase of hydrogen refuelling station in Germany worldwide in 2018 again, TUV SudAmerica Inc., https://www.globenewswire.com/news-release2019/02/15/1726095/en/High est-increase-of-hydrogen-refuelling-station-in-Germany-wordwoide-in-2018-again.html.

[11] How hydrogen empowers the energy transition, Hydrogen Council, 2017.

[12] Hydrogen Scaling Up, A sustainable pathway for the global energy transition, Hydrogen Council, November 2017.

[13] Hyundai's next-generation fuel cell vehicle NEXO Boats world's best driving range, Hyundai Motor America, https://www.hyundainews.com/en/-us/release/2490, 19 February 2018.

[14] IHS forecasts FCEV production for each 69.000 up by 2027, IHS Markit, May 2016, https://ihsmarkit.com/researchanalysis/ihs-forecasts-fcev-production, 2016.

[15] International partnership for hydrogen and Fuel Cell in the economy, country update, November 2018-April 2019, https://www.iphe.net, access from 23 May 2019.

[16] MacEven, R., Our countdown of the top 5 developments in the Hydrogen and Fuel Cell, Industry in 2018, January 2019, https://blog.ballard.com/hydrogen-and-fuel-cell-industry and Wong A.: Status of Hydrogen and Fuel Cell related Business in China, ICEF, Tokyo, October 2018. 
[17] The end of a long wait, 1 June 2018 https://www.daimler.com/innovation/next/the-end-of-along-wait.html.

[18] Weeda, M, et al., Towards a Comprehensive Hydrogen Infrastructure for Fuel Cell electric cars in View of EU GHG Reduction Targets, HIT European Project, 2014.

Manuscript received 01 August 2019; approved for printing 09 December 2019 